\title{
Analysis of the effectiveness of ActivLife training in people over 60 years of age: A pilot study
}

\author{
Anna Leś $\mathrm{PhD}^{\mathrm{a}, *}$ \\ Ewa Niedzielska $\mathrm{PhD}^{\mathrm{b}}$ \\ Joanna Piotrowska $\mathrm{PhD}^{\mathrm{b}}$ \\ Michał Staniszewski PhD ${ }^{\mathrm{c}}$ \\ Dominika Kozak PhD ${ }^{d}$
}

\begin{abstract}
aózef Piłsudski University of Physical Education in Warsaw, Faculty of Tourism and Recreation, Department of Recreation, Division of Theory of Recreation; bózef Piłsudski University of Physical Education in Warsaw, Faculty of Tourism and Recreation, Department of Recreation, Division of Metodics of Recreation; 'Józef Piłsudski University of Physical Education in Warsaw, Faculty of Physical Education, Department of Sports, Division of Water and Winter Sports;

${ }^{\mathrm{d}}$ Alreh Medical, Warsaw, Poland; *Corresponding author: les.anna@wp.pl
\end{abstract}

\begin{abstract}
A. Leś, E. Niedzielska, J. Piotrowska, M. Staniszewski, D. Kozak. Analysis of the effectiveness of ActivLife training in people over 60 years of age: A pilot study. Gerontechnology 2017;16(3):189-195; https://doi.org/10.4017/gt.2017.16.3.008.00 Background One of the most important geriatric problems which increases the risk of injury and disability is falling. The consequences involve fractures of the hips and femoral neck, leading to restrictions in mobility, independence and the quality of life. Reduction of the risk is the main challenge of modern geriatrics. Aim The aim of the study was to analyze the effectiveness of training using the ActivLife system in women over 60 years of age who have declared difficulties in maintaining the balance of the body. Method The study covered a group of 14 women over 60 years of age. The experimental group participated in a 4-week program with the use of the ActivLife system and the author's exercise program providing assistance in maintaining balance. The Fullerton Functional Fitness Test as well as measurements on a baropodometric platform were applied to assess the effectiveness of the activities. Results In the experimental group, a positive correlation ( $r=0.769$ ) was observed between the results of attempting to perform the 'Two minute step test' and the 'Chair Stand' ( $r=0.850$ in the control group). In addition, the studied group experienced a significantly negative correlation $(r=-0.838)$ between the results of attempting to perform the 'Up-and-Go' and the 'chair Stand' (the control group presented a negative correlation of $r=-0.856)$. In the selected attempts related to fitness and balance, dependencies between different parameters can be observed.
\end{abstract}

Keywords: fall, balance, seniors, physical activity, computer program

Falls are one of the most important geriatric problems increasing the risk of injury and disability in people over 65 years of age. This problem is associated with the increased morbidity and mortality in the elderly population ${ }^{1,2}$. It is reported that the fifth most common cause of death in the older adults involves injuries which are a consequence of falling. The most common consequences include fractures of the hips and the femoral neck, leading to restrictions in mobility, independence and the quality of life. The study carried out among people hospitalized due to a fall proved that only $50 \%$ of older adult patients survive one year after having left the hospital ${ }^{4}$. Therefore, reducing the risk of a fall is a major challenge for modern geriatrics, public health and health care.
There is a number of external and internal determinants which increase the risk ${ }^{5-7}$ when occurring at the same time. However, balance and the ability to maintain a stable body posture are significant indicators for prevention ${ }^{8,9}$. One of the main elements of successful ageing is maintaining physical fitness allowing for independent functioning in everyday life. However, physiological involutional processes occurring with age lead to a decrease in overall health, muscle weakness, gait and balance disorders. This state of affairs can significantly weaken the functioning of older adults during the day ${ }^{10}$.

Physical exercises improving balance are an essential part of risk prevention programs con- 
cerning falls ${ }^{11,12}$. Balance training constitutes an effective intervention in reducing the risk of a fall among the older adults with DPN (Diabetic Peripheral Neuropathy) ${ }^{13}$. Studies have shown that balance disorders are the most important factor which increases the risk among people with symptoms of diabetes ${ }^{14}$. The application of effective balance training in physiotherapy based on proprioceptive exercises, strength training of the lower limbs and atrial stimulation exercises are recommended by review studies for the reduction of the risk of a fall among the older adults with DNP ${ }^{15}$. The effectiveness of balance training for fall prevention has also been confirmed by studies carried out in a group of older adult people who had experienced a fall within 12 months prior to the study ${ }^{16}$. Traditional intervention programs for reducing the risk of a fall are based on physical activity that contains elements of training, balance, endurance, strength, reaction time, functional exercises ${ }^{17-20}$. One solution is to include virtual reality into the intervention programs. The combination of console games and devices for exercising balance is the right strategy for fall prevention ${ }^{21}$. This seems to confirm the study results on virtual reality application in physical therapy in patients with symptoms of a damaged peripheral vestibular organ. In randomized studies, one group of patients exercised on a posturographic platform, the second one used a program based on virtual reality. After two weeks of exercises in both groups, the developed area and the swing length of the stabilogram gravity centre in different variants of stimulations was reduced ${ }^{22}$. The effectiveness of virtual reality in balance training has also been confirmed by a randomized study conducted on a group of veterans of $68( \pm 6.7)$ years of age. In the group, a Wii-Fit (Nintendo Wii-Fit $\left.{ }^{\circledR}\right)$ balance training exercise program was applied. After an 8-week period of exercises, the experimental group reported significant improvements of balance compared to the control group ${ }^{23}$. In a number of studies, relevant exercises prove to be the most effective element of the prevention of falls in the elderly ${ }^{24-28}$. On the other hand, the same therapeutic intervention based on console games does not bring the expected results in the form of improved balance. In Bateni studies, the highest balance improvement was observed in the group involved in classic physiotherapy classes combined with Nintendo Wiiß games ${ }^{29}$.

The ActivLife rehabilitation device is designed to activate the motor and mental activity of people of age whose daily activity levels have decreased. ActivLife is applied in the prevention of falls of the older adults, and due to the simultaneous combination of motor and mental exercises, it provides effective support for cognitive processes. The device is equipped with a mechanism assisting in standing up called GymUp, allowing for mobility exercises of the ankle, knee and hip joints. It increases muscle strength of the lower limbs while performing squats and back stances. A special corset and seat ensure safety during exercises strengthening the back and abdomen muscles based on lifting the legs. ActivLife also allows to maintain a safe, upright standing position, and to perform balancing exercises as well as exercises activating the upper parts of the body using the multimedia program. The multimedia program also effectively supports cognitive processes during physical and mental exercises. ActivLife is an innovative device which, through movements of the body, uses the patient's interactions with games to measure mobility and improve overall physical fitness.

This modern technology can change the lifestyle of the older adults from sedentary to more active. The software contains exercise modules (cognitive, memory, logical thinking, coordination, general improvement) with varying degrees of difficulty. A simple operating system, remote control for changing programs, control system, possibility to use additional accessories-all this allows to use the device at home. ActivLife can be effectively used in intervention programs to reduce the risk of falling among older adults. Therefore, the aim of this study was an analysis of balance training efficiency with the use of the innovative ActivLife device in people over 60 years of age (retrieved April 25, 2017 from http://www.activlife.eu)

\section{Methods \\ Participants}

The study covered a group of 14 women over 65 years of age, reporting problems with maintaining balance, tripping or falling. The women did not participate in organized fitness activities. The study was randomly divided into two groups-an experimental group (7 people) and a control group (7 people). The women provided their written consent for participation in the study. The characteristics of the groups are shown in Table 1.

\section{Measures}

Prior to the program, both groups were tested in terms of fitness. Baropodometric platform measurements were also performed. The measurements were repeated in both groups after 4 weeks. The studies involved fitness attempts, consisting of the Fullerton Functional Fitness

Table 1. Characteristics of the studied group $(\Sigma \pm S D)$

\begin{tabular}{lcc}
\hline Data & $\begin{array}{c}\text { Experimental } \\
\text { group }(\mathbf{n}=7)\end{array}$ & $\begin{array}{c}\text { Control group } \\
(\mathbf{n}=7)\end{array}$ \\
\hline Age (years) & $72.5( \pm 5.4)$ & $73.5( \pm 4.5)$ \\
Body height $(\mathrm{cm})$ & $157.6( \pm 2.5)$ & $158.4( \pm 5.6)$ \\
Body weight $(\mathrm{kg})$ & $64.7( \pm 9.4)$ & $63.8( \pm 13.4)$ \\
\hline
\end{tabular}


Test. 6 fitness attempts were carried out ${ }^{30}$ :

(i) Chair stand (assessment of muscle strength of the lower limbs; number of repetitions);

(ii) Two-minute Step Test (assessment of strength; number of RL-LL cycles);

(iii) Up and Go (assessment of agility and dynamic balance, assessment of the risk of falling; walking time);

(iv) Back Scratch Test (assessment of mobility of the upper part of the body; $\mathrm{Cm}$ );

(v) Chair sit-and-reach (assessment of the mobility of the lower spine; $\mathrm{cm}$ );

(vi) Arm Curl (assessment of muscle strength of the upper limbs; number of repetitions).

Postural stability measurements were carried out with the use of the FreeMedSensor Medica (Italy) stable-metric platform with the FreeStepver software. 1.4.01. Two measuring protocols were performed while standing with bare feet for approximately 30 seconds: both with eyes open and closed while standing on both feet. For the purposes of analyses and comparison, path distance values of the footprint on the ground (COP), the path area ellipse size of the footprint on the ground (COP), as well as the range of maximum fluctuations were used. Three fitness attempts (Up and Go, Chair Stand, Two-minute step test) and three parameters of balance measurements (indicated above) were selected as the most important aspects in the prevention of falls in the older adults.

\section{Procedures}

For 4 weeks, the experimental group participated in individual activities (exercises), focused on the prevention of falls. The physical activities were carried out with the use of the ActiveLife system (computer software->Fitness> module and the stander) and the author's program of 14 exercises. The experimental group participated in a total of 8 training units (one unit lasted 35-40 minutes).

\section{Statistical analyses}

The Statistica 12 programme package was used to analyse the results. An analysis of Pearson's simple correlation coefficients was performed (the results of selected fitness attempts and data obtained from the stabilometric platform), as well as an analysis of the ANOVA variance for repeated measurements before and after bodybalance training. The significance level $p<0.05$ was considered to be statistically significant.

\section{Results}

The study covered a group of 14 women living in a large city, professionally inactive (retired). Detailed characteristics of the experimental and control groups are shown in Table 1 (below).

Three fitness attempts were carried out in the groups to examine the aspects which are mostly related to falls and tripping. The average results of the selected fitness attempts and measurements on the balance platform in the experimental and control groups have been summarized in Table 2. There were no statistically significant differences between the measurements carried out before and after the 4 -week period of exercise. The range of maximum fluctuations increased $(p<0.05)$, in body stability measurements on the stabilometric platform with eyes kept closed, whereas the path length and the field drawn by that path (ellipse area) did not differ significantly between measurements with eyes open and closed.

After analysis of both measurements of fitness attempts, a correlation between the individual results in the studied groups can be observed. In the experimental group, one recorded a positive correlation $(r=0.769)$ between the results of attempting the "Two-minute step test" and the "Chair Stand" ( $r=0.850$ in the control group). In addition, the experimental group experienced a significantly negative correlation $(r=-0.838)$ between the results of attempting the "Up-and-Go" and the "Chair Stand" (a negative correlation $r=-0.856$ in the control group). During analysis of the results of the studies related to balance and selected fitness attempts, relationships between individual parameters can be observed. Table 3 presents the correlation coefficient values $(r)$.

Table 2. Average $\pm S D$ results of the fitness attempts and the measurements on the platform with open eyes (OO) and closed (OZ) standing on both feet

\begin{tabular}{lcccc}
\hline Attempt & \multicolumn{2}{c}{ Experimental group } & \multicolumn{2}{c}{ Control group } \\
\cline { 2 - 5 } & 1st measurement & 2nd measurement & 1st measurement & 2nd measurement \\
\hline Up\&Go $(\mathrm{s})$ & $7.08( \pm 0.62)$ & $6.58( \pm 0.92)$ & $6.52( \pm 1.35)$ & $7.59( \pm 2.84)$ \\
Standing up from a chair $(\mathrm{n})$ & $14.29( \pm 1.79)$ & $17.86( \pm 2.91)$ & $13.71( \pm 3.25)$ & $15.71( \pm 3.73)$ \\
March in place 2' $(\mathrm{n})$ & $77.43( \pm 18.98)$ & $83.86( \pm 21.48)$ & $75.43( \pm 17.01)$ & $84.86( \pm 21.54)$ \\
Ellipse size $\left(\mathrm{cm}^{2}\right)$ OO & $92( \pm 150)$ & $53( \pm 78)$ & $41( \pm 32)$ & $38( \pm 20)$ \\
Ellipse size $\left(\mathrm{cm}^{2}\right)$ OZ & $134( \pm 164)$ & $97( \pm 68)$ & $121( \pm 98)$ & $92( \pm 69)$ \\
Length of path COP $(\mathrm{mm})$ OO & $170( \pm 23)$ & $177( \pm 33)$ & $171( \pm 42)$ & $178( \pm 37)$ \\
Length of path COP $(\mathrm{mm})$ OZ & $198( \pm 37)$ & $252( \pm 88)$ & $225( \pm 44)$ & $247( \pm 69)$ \\
Max. fluctuations $(\mathrm{cm})$ OO & $1.47( \pm 0.91)$ & $1.09( \pm 0.37)$ & $1.54( \pm 0.82)$ & $1.12( \pm 0.31)$ \\
Max. fluctuations $(\mathrm{cm})$ OZ & $5.45( \pm 4.55)$ & $14.78( \pm 10.22)$ & $10.27( \pm 9.73)$ & $10.64( \pm 5.72)$ \\
\hline
\end{tabular}


Table 3. Correlation coefficients between the path length of the footrest on the ground (COP) standing on both feet with open eyes and fitness tests - joint analysis for both groups $(\mathrm{N}=14)$; ${ }^{*}$ correlation coefficients are significant at $p<0.05$

\begin{tabular}{lc}
\hline Variable & Path length COP \\
\hline Two minute step test & $-0.610^{*}$ \\
Chair sit and reach (left leg) & $-0.757^{*}$ \\
Chair sit and reach (right leg) & $-0.815^{*}$ \\
Back scratch test (left hand) & -0.235 \\
Back scratch test (right hand) & -0.421 \\
Chair stand & -0.446 \\
Up and Go & $0.719^{*}$ \\
Arm Curl (left hand) & $-0.572^{*}$ \\
Arm Curl (right hand) & -0.483 \\
\hline
\end{tabular}

Body stability values expressed by the length of the footpath on the ground during stabilometric platform measurements correlate significantly with the fitness attempts related to the participants' mobility, i.e. the 'Two-minute step test', 'Chair sit and reach' and 'Up and Go'.

\section{DisCUSSION AND CONCLUSIONS}

Regular physical activity plays a big role in every stage of ontogenesis. However, until recently, the problem of health behaviour of the older adults had not been analysed often in the past years. Systematic physical activity should be included in the lives of older adults. Unfortunately, their daily activities during the day are not sufficient to meet the WHO recommendations on the required minimum and to meet the proper fitness levels ${ }^{31}$. That is why specialized programs are needed to properly impact on the key parameters such as muscle strength or dynamic balance, as well as cognitive factors. The study participants did not undertake other organized forms of activities mainly due to health reasons.

In fact, every motor activity is associated with the displacement of the centre of gravity in relation to its optimal position. Every complex movement (climbing on toes and movements of the lower limbs, head, quads) will cause destabilization of body posture to various extents ${ }^{32}$. It must be noted that the older adults have a limited range and speed of movement. As the body ages, muscle weight and strength decreases. With a decrease in muscle strength, the body must be kept in balance, and this is expressed by an increase in the speed of movement of the centre of gravity (reaction point of the substrate reaction force $)^{33}$ and its total path in a standing position in two planesfrontal and sagittal ${ }^{32}$.

Taking into account all activities undertaken by the older adults, more and more attention is paid to strength training. According to Granach et al., a combination of multi-tasking balance training which includes deliberate actions interrupting a person from maintaining a standing position as well as strength training, was the best method to reduce the risk of falls in seniors ${ }^{34}$.

One of the attempts discussed in the present study (gate shot defence or boxing attempt) was intended to precipitate the participant along with the correctly carried out task, however at the same time it was associated with the high speed at which the task was to be carried out. The experimental group subjected to monthly training gained better results in the Up and Go test. In the second group, despite an increase in the number of repetitions in the attempts to stand up from a chair, the results were worse in the Up and Go. The increased time may indicate more careful gait and a defensive strategy in the form of striving for a sense of security. In the study of Skalska and Gałaś, the longer time taken in this attempt increased the risk of a fall by 4.5 times. This is especially justified in the case of the older adults diagnosed with osteoporosis ${ }^{35}$. A disturbed dynamic balance, weak reflexes and poorer spatial orientation translate into a much worse result ${ }^{36}$. However, with the increasing intensity of this phenomenon, unfavourable changes at the level of functional efficiency may result, which in turn may lead to a fall and its consequences ${ }^{37,38}$. On the other hand, Agmon $\mathrm{M}$ et al. intervened in terms of seven people at 84 years of age ${ }^{39}$. The program based on Nintendo Wii Fit lasted 3 months, with a frequency of 3 times a week for the duration of $30 \mathrm{~min}$. However, after 50 training sessions, gait speed measured with the Timed 4-Meter Walk test increased. Considering the 'Up on Go', there was a significant negative correlation with the COP path length, which confirms the fact that a shorter duration of the attempt results in fewer swings, and therefore increases control of stability, speed and gait, reducing the risk of a fall.

Taking into account the COP path length, no significant differences were found between the groups, especially in the studied group before and after intervention. Famuła et al. described the efficiency of the body's regulation and stability in terms of their daily physical activity ${ }^{40}$. There were 66 people undertaking low and medium exercises. When assessing the COP path patch, there was greater sensitivity to the postural changes in seniors who were moderately active, however the changes were not statistically significant. It can therefore be concluded that only regular and correctly selected activity can bring the expected changes at a balance level.

Increased muscle strength is crucial for improvement in the older adults, but in Poland there is greater focus on endurance and stretching exercises. Unfortunately, there are no programs where 
muscle strength is expanded ${ }^{33}$. The strength of the lower limb muscles is largely determined by improvement in functional tests. During the experiment, the participants exercised in accordance with the ActiveLife program, with an addition of a recommended set of balance exercises. At the end of the program, correlations between the first and second attempt to stand up from a chair were recorded. This attempt depends on the strength of the lower limb muscles, however in the 4th phase (stabilization phase), when the hip is straightened and the position is changed to a standing one, it is very important to keep postural stability $^{41}$. Standing up from a chair and actually changing position from sitting to standing and vice versa is conditioned by a number of other factors, it is one of the most common activities of the day. It is also an activity which influences speed increase and balance while walking. In the presented study, there was no significant correlation between this sample and the COP path length which may indicate that the program is not long or intensive enough. At the same time, there was a significant negative correlation observed between the 'Two-minute step' and the 'Chair sit and reach' (right and left leg) which also confirms the fact that strength improvement, as well as flexibility of the lower body parts, have an effect on increasing postural stability in the older adults.

Cognitive functions also play a very important role. The older adults are afraid to undertake activities of advanced difficulty, especially when it comes to those that require sudden decisions or changes of the previously learned programs. A major problem for the older adults seems to be the need to perform under pressure of time or such which are difficult to perform due to visual or auditory impairment, or as a result of a sudden change in external factors (e.g. of road surface) ${ }^{42}$. This was the main reason for falls in the case of the participants of the study. Decreased cognitive functions in the older adults may impair the compensation of gait and balance ${ }^{43}$. There is a great deal of attention paid towards regulating gait. Performing an additional task during gait may reduce its speed or decrease the performed cognitive task. Results of numerous studies confirm that the addition of a second cognitive task made gait difficult for both those who fell and those who did not ${ }^{44-46}$. In the presented study, it may also be observed that in people with a lower centre of gravity swings during the dynamic balance attempt, a shorter duration of all tasks in ActiveLife was observed during each training session.

Therefore, the use of various additional tasks in the program during the exercise will provide opportunities for improving postural stability in the older adults, as well as increase walking speed which will ultimately have an effect on reducing the risk of falls.

In the study, it was also observed that people who had already fallen in their lives achieved significantly worse results in terms of functional efficiency compared to those who had never had such an experience ${ }^{11}$. Melzer et al observed that seniors with advanced stability deficits who had previously experienced a fall had an increase in the scales of the centre of gravity swings on the supporting plane in a standing position with joined feet ${ }^{47}$.

There is a correlation between the 'Two-minute test' and the 'Chair stand test', as well as between the 'Up and Go' and the 'Chair stand test'. It shows a tendency for changes in other parameters during extended program duration.

More and more analyses of various programs aimed at improving functional efficiency are emerging in literature to minimize the risk of falls. These programs apply appropriately selected physical exercises aimed at improvement in the older adults. However, a growing number of people are joining computer programs and physical exercises ${ }^{29}$.

The results of the study indicate that there is a connection between the combination of balance-oriented physical exercises combined with modern motion-activated multimedia programs; however, attention should be paid to strength exercises. In addition, it seems necessary to separate appropriately selected exercises aiming at balancing from the ActivLife program to verify the strength of one stimulus.

Considering the constantly growing number of older adults, it is necessary to develop different solutions and to implement adjusted programs using specialized tools to minimize the risk of their falls. The programs should mainly be directed at increasing muscle strength, improving body balance and coordination. Modern methods allow to individually select a program for fall prevention. All types of programs which use gamification may be a great way to prevent falls or help with the rehabilitation process due to a complication caused by falling, as well as be an important motivator in the improvement process.

\section{LimitATION OF THE STUDY}

Although the research has reached its targets, there were some unavoidable limitations. First, it was conducted on a small-sized population. Therefore, in order to generalize the results for larger groups, the study should have involved more participants. Secondly, due to the time limit, the experimental group participated in individual activities (exercises) for a period of only 4 weeks. Future research should last a longer amount of time, e.g. 12 weeks. 


\section{Acknowledgements}

We sincerely thank our colleagues from University of Physical Education in Warsaw, for their active participation in the study and comments that greatly improved the manuscript.

\section{References}

1. Hausdorff JM, Rios DA, Edelberg HK. Gait variability and fall risk in community-living older adults: a 1-year prospective study. Archives of Physical Medicine and Rehabilitation 2001;82(8):10501056; https://doi.org/10.1053/apmr.2001.24893

2. Tinetti ME. Clinical practice. Preventing falls in elderly persons. The New England Journal of Medicine 2003;348(1):42-49; https://doi.org/10.1056/ NEJMcp020719

3. Borowicz AM, Wieczorowska-Tobis K. Ocena ryzyka upadku u osób starszych przebywających na oddziale rehabilitacji [The assessments of the risk of falls in elderly subjects on rehabilitation ward]. Geriatria 2011;5:13-18

4. Tideiksaar R. Falls in Older People. Health Professions Press, Baltimore, Md, USA 2016, 3rd edition; https://doi.org/10.1177/073346489901800211

5. Świątek J, Urodow W. Profilaktyka upadków u ludzi w podeszłym wieku. [Prevention of Falls of the Elderly People] Pielęgniarstwo i Zdrowie Publiczne 2013;3(2):195-200

6. Cameron ID, Gillespie LD, Robertson MC, Murray $G R$, Hill $K D$, Cumming $R G$, Kerse N. Interventions for preventing falls in older people in care facilities and hospitals. Cochrane Database of Systematic Reviews 2012;12:1-76; https://doi. org/10.1002/14651858.CD005465.pub3

7. WHO: WHO global report on falls prevention in older age. World Health Organization, Geneva 2007

8. Ganz DA, Bao Y, Shekelle PG, Rubenstein LZ. Will my patient fall? JAMA 2007;297(1):77-86; https://doi.org/10.1001/jama.297.1.77

9. Żak M. Determinanty powtarzalności upadków u osób po 75 roku życia.[ Determinants of repeatability of falls in persons aged 75 years] Akademia Wychowania Fizycznego im. Bronisława Czecha, Kraków 2009;1-116

10. Thornby MA. Równowaga i upadki u osłabionej osoby starszej: przegląd literatury.[ Balance and falls in the frail older person: a review of the literature] Rehabilitacja Medyczna 1997;4(1):11-18; https://doi.org/10.1016/s0031-9406(05)65719-7

11. Kubica JL. Ocena zależności pomiędzy ryzykiem upadków i sprawnością fizyczną a występowaniem upadków wśród pensjonariuszy prywatnych domów opieki [Assessment of correlation of risk of falls and physical fitness and occurrence of falls among private nursing home residents]. Hydeia Public Health 2015;50(1):177-182

12. Howe TE, Rochester L, Jackson A, Banks PMH, Blair VA. Exercise for improving balance in older people. Cochrane Database of Systematic Reviews 2007, 4 (2007): CD004963; https://doi. org/10.1002/14651858.CD004963.pub2

13. Pan X, Bai J. Balance training in the intervention of fall risk in elderly with diabetic peripheral neuropathy: A review. International Journal of Nursing Sciences 2014;1(4):441-445; https://doi. org/10.1016/j.ijnss.2014.09.001

14. Cavanagh PR, Derr JA, Ulbrecht JS, Maser RE, Orchard TJ. Problems with gait and posture in neuropathic patients with insulin-dependent diabetes mellitus. Diabetic Medicine 1992;9(5):469-474; https://doi.org/10.1111/j.1464-5491.1992.tb01819.x

15. Pan X, Bai J. Balance training in the intervention of fall risk in elderly with diabetic peripheral neuropathy: A review. International Journal of Nursing Sciences 2014;1(4):441-445; https://doi. org/10.1016/j.ijnss.2014.09.001

16. Choi JH, Kim NJ. The effects of balance training and ankle training on the gait of elderly people who have fallen. Journal of Physical Therapy Science 2015;27(1):139-142; https://doi.org/10.1589/jpts.27.139

17. Zak M, Swine Ch, Grodzicki T. Combined effects of functionally- oriented exercise regimens and nutritional supplementation on both the institutionalized and free-living frail elderly (double-blind, randomized clinical trial). BMC Public Health 2009;9:39; https://doi.org/10.1186/1471-2458-9-39

18. Sherrington C, Whitney J, Lord S, Herbert R, Cumming R, Close J. Effective exercise for the prevention of falls_ a systematic review and meta-analysis. Journal of the American Geriatrics Society 2008;56(12):2234-2243; https://doi.org/10.1111/ j.1532-5415.2008.02014.x

19. Barnett A, Smith B, Lord SR, Williams M, Baumand A. Community-based group exercise improves balance and reduces falls in at-risk older people: a randomized controlled trial. Age Ageing 2003;32(4):407414; https://doi.org/10.1093/ageing/32.4.407

20. Halvarsson A, Dohrn IM, Ståhle A. Taking balance training for older adults one step further: the rationale for and a description of a proven balance training programme. Clinical Rehabilitation 2015;29(5):417-425; https://doi. org/10.1177/0269215514546770

21. Żak M, Krupnik S, Puzio G, Staszczak-Gawełda I, Stopa A, Czesak J. Wykorzystanie wirtualnej rzeczywistości i gier konsolowych w profilaktyce upadków osób starszych [Making use of virtual reality and console gaming in falls prevention among the elderly]. Gerontologia Polska 2014;22(1):9-13

22. Józefowicz-Korczyńska M, Walak J, Szczepanik M, Lukas Grzelczyk W, Rosiak O. Ocena zastosowania wirtualnej rzeczywistości jako metody fizjoterapii w uszkodzeniu obwodowym narządu przedsionkowego [Evaluation of Virtual Reality training in the treatment of peripheral vestibular system impairment]. Otorynolaryngologia 2014;13(1):51-57; https://doi.org/article-a6273a60b6ee-4f0a-9646-cdf8fbe51f5c

23. Padala KP, Padala PR, Lensing SY, Dennis RA, Bopp MM, Parkes CM, Garrison MK, Dubbert PM, Roberson PK, Sullivan DH. Efficacy of WiiFit on Static and Dynamic Balance in Community Dwelling Older Veterans: A Randomized Controlled Pilot Trial. Journal of Aging Research 2017: Article ID 4653635, 9 pages; https://doi. org/10.1155/2017/4653635

24. Gardner MM, Robertson MC, Campbell AJ. Exer- 
cise in preventing falls and fall related injuries in older people: a review of randomised controlled trials. British Journal of Sports Medicine 2000;34(1):717; https://doi.org/10.1136/bjsm.34.1.7

25. Day L, Fildes B, Gordon I, Fitzharris M, Flamer $H$, Lord S. Randomised factorial trial of falls prevention among older people living in their own homes. BMJ 2002;325(7356):128-131; https://doi. org/10.1136/bmj.325.7356.128

26. Low S, Ang LW, Goh KS, Chew SK. A systematic review of the effectiveness of Tai Chi on fall reduction among the elderly. Archives of Gerontology and Geriatrics 2009;48(3):325-331; https://doi. org/10.1016/j.archger.2008.02.018

27. Maciaszek J, Osiński W. The Effects of Tai Chi on Body Balance in Elderly People- A Review of Studies from the Early 21st Century. The American Journal of Chinese Medicine 2010;38(2):219-229; https://doi.org/10.1142/S0192415X10007798

28. Skelton D,Dinan S,Campbell M,Rutherford O. Tailored group exercise (Falls Management Exercise - FaME) reduces falls in community-dwelling older frequent fallers (an RCT). Age Ageing 2005;34(6):636639; https://doi.org/10.1093/ageing/afi174

29. Bateni $H$. Changes in balance in older adults based on use of physical therapy vs the Wii Fit gaming system: A preliminary study. Physiotherapy 2012;98(3):211-216; https://doi.org/10.1016/j. physio.2011.02.004

30. Jones CJ, Rikli RE. Measuring functional fitness of older adults. Journal on active aging 2002;1:24-30

31. Halat B, Brudz D, Milewicz K, Pop T, Śliwiński Z. Wpływ ćwiczeń ogólnousprawniających na równowagę i chód osób w podeszłym wieku, przebywających w oddziale ZOL w Legnicy [The Influence of General Fitness Training on Balance and Gait of the Elderly Staying in the Chronic Medical Care Ward in Legnica]. Przegląd Medyczny Uniwersytetu Rzeszowskiego i Narodowego Instytutu Leków w Warszawie 2004;1:84-96

32. Błaszczyk J. Czerwosz L. Stabilność posturalna w procesie starzenia [Postural stability in the process of aging]. Gerontologia Polska 2005;13(1):25-36

33. Trzaskoma Z. Maksymalna siła mięśniowa i moc maksymalna kobiet i mężczyzn uprawiających sport wyczynowo: Studia i monografie [Maximum muscle strength and maximal power of men and women practicing professionally: Studies and monographs]. Akademia Wychowania Fizycznego Józefa Piłsudskiego w Warszawie 2003

34. Granacher U, Muehlbauer T, Zahner L, Gollhofer A, Kressig RW. Comparison of traditional and recent approaches in the promotion of balance and strength in older adults. Sports Med 2011;41(5):377-400; https:// doi.org/10.1007/s40279-013-0041-1

35. Skalska A, Gałaś A, Upadki jako czynnik ryzyka pogorszeniastanu funkcjonalnego w starszym wieku [History of falls as a risk factor for functional decline in the elderly]. Gerontologia Polska 2011;19(3-4):150-160

36. Szczepaniak R, Brzuszkiewicz-Kuźmicka G, Szczepkowski M, Pop T, Śliwiński Z. Ocena aktywności ruchowej i sprawności fizycznej kobiet po 65 roku życia, ze zdiagnozowaną osteoporozą. Doniesienia wstępne [Evaluation of the motor activity and physical fitness of women over 65 years of age diagnosed with osteoporosis]. Preliminary reports. Przegląd Medyczny Uniwersytetu Rzeszowskiego i Narodowego Instytutu Leków w Warszawie 2014;1:62-73

37. Delbaere K, Crombez G, Vanderstraeten G, Willems T, Cambier D, Fear-related avoidance of activities, falls and physical frailty. A prospective communitybased cohort study. Age Ageing 2004;33(4):368-73; https://doi.org/10.1093/ageing/afh106

38. Brouwer B, Musselman K, Culham E. Physical function and health status among seniors with and without a fear of falling. Gerontology 2004;50:135141; https://doi.org/10.1159/000076771

39. Agmon M, Perry CK, Phelan E, Demiris G, Nguyen HQ. A pilot study of Wii Fit exergames to improve balance in older adults. Journal of geriatric physical therapy 2011;34(4):161-167; https://doi. org/10.1519/JPT.0b013e3182191d98

40. Famuła A, Nowotny J, Nowotny-Czupryna A, Kita B, Szymańska J. Stabilność ciała osób w podeszłym wieku w aspekcie ich codziennej aktywności ruchowej [Body stability of the elderly in the aspect of their daily physical activity] Postępy Rehabilitacji 2012 5-14; https://doi. org/10.2478/rehab-2013-0032

41. Schenkman M, Hughes MA, Samsa G, Studenski $\mathrm{S}$. The relative importance of strength and balance in chair rise by functionally impaired older individuals. Journal of the America Geriatrics Society 1996;44:1441-1446

42. Rajtar-Zembaty A, Rajtar-Zembaty J, Epa1 R, Starowicz-Filip A. Związek między funkcjonowaniem poznawczym a sprawnością funkcjonalną u osób starszych [The relationship between cognitive functioning and functional capability in older adult]. Geriatria 2016;10:78-84

43. Yogev-Seligmann G, Hausdorff J, Giladi N. The role of executive function and attention in gait. Movement Disorders 2008;23:329-42; https://doi. org/10.1002/mds. 21720

44. Beauchet O, Dubost V, Herrmann F, Rabilloud M, Gonthier R, Kressig RW: Relationship between dual-task related gait changes and intrinsic risk factors for Falls among transitional frail old eradults. Aging clinical and experimental research 2005; 17:270275; https://doi.org/10.1007/bf03324609

45. Springer S, Giladi N, Peretz C, Yogev G, Simon ES, Hausdorff JM: Dual-taskingeffects on gait variability: the role of aging, falls, and executive function. Movement Disorders 2006;21:950-957; https://doi. org/10.1002/mds.20848

46. Taylor ME, Delbaere K, Mikolaizak AS, Lord SR, Close JC: Gait parameter risk factors for Falls under simple and dual task conditions in cognitively impaired older people. Gait Posture 2013;37:126-130; https://doi.org/10.1016/j.gaitpost.2012.06.024

47. Melzer I, Benjuya N, Kaplanski J. Postural stability in the elderly: a comparison between fallers and non-fallers. Age and Ageing 2004;33(6):602-607; https://doi.org/10.1093/ageing/afh218 